\title{
Heterogeneity in Allergy to Mollusks: A Clinical-Immunological Study in a Population From the North of Spain
}

\author{
Azofra J', Echechipía S, Irazábal B³, Muñoz D4, Bernedo N4, García BE², \\ Gastaminza $\mathrm{G}^{5}$, Goikoetxea $\mathrm{M}^{\mathrm{a}} \mathrm{J}^{5}$, Joral $\mathrm{A}^{6}$, Lasa $\mathrm{E}^{6}$, Gamboa $\mathrm{P}^{7}$, Díaz $\mathrm{C}^{1}$, \\ Beristain $A^{1}$, Quiñones $D^{1}$, Bernaola $G^{8}$, Echenagusia $\mathrm{MA}^{9}$, Liarte $\mathrm{I}^{3}$, García $\mathrm{E}^{7}$, \\ Cuesta $\mathrm{J}^{10}$, Martínez $\mathrm{M}^{\mathrm{a}} \mathrm{D}^{3}$, Velasco $\mathrm{M}^{4}$, Longo $\mathrm{N}^{4}$, Pastor-Vargas $\mathrm{C}^{11}$
}

'Sección de Alergia, Área de Gestión del Pulmón, Hospital Universitario Central de Asturias, Oviedo, Spain ${ }^{2}$ Servicio de Alergia, Complejo Hospitalario de Navarra, Pamplona, Spain

${ }^{3}$ Servicio de Alergia, Hospital de Cruces, Bilbao, Spain

${ }^{4}$ Servicio de Alergia, Hospital Universitario de Araba, Vitoria, Spain

${ }^{5}$ Departamento de Alergia, Clínica Universidad de Navarra, Pamplona, Spain

${ }^{6}$ Servicio de Alergia, Hospital Donostia, San Sebastián, Spain

${ }^{7}$ Servicio de Alergia, Hospital de Basurto, Bilbao, Spain

${ }^{8}$ Servicio de Alergia, Hospital de Galdácano, Bilbao, Spain

${ }^{9}$ Servicio de Alergia, Hospital de Mendaro, Guipúzcoa, Spain

${ }^{10}$ Departamento de Alergia, Fundación Jiménez Díaz, Madrid, Spain

"Departamento de Inmunología, IIS Fundación Jiménez Díaz, UAM, Madrid, Spain

J Investig Allergol Clin Immunol 2017; Vol. 27(4): 252-260

doi: 10.18176/jiaci.0137

\section{Abstract}

Background: Allergy to mollusks has been the focus of fewer studies than allergy to crustaceans. Furthermore, allergy to mollusks is less well characterized.

Objectives: To describe the clinical characteristics of mollusk-allergic patients, to identify the responsible allergens, and to assess crossreactivity.

Methods: We performed a prospective multicenter study including 45 patients with mollusk allergy, which was diagnosed based on a suggestive clinical history and a positive skin test result with the agent involved. Fractions were identified using SDS-PAGE and immunoblotting. The proteins responsible were subsequently identified using mass spectrometry. ELISA inhibition studies were performed with mollusks, dust mites, and crustaceans.

Results: We found that 25 patients (55\%) were allergic to cephalopods, $14(31 \%)$ to bivalves, and $11(24 \%)$ to gastropods. Limpet was the third most frequent cause of allergy (15\% of cases). In 31 patients (69\%), the manifestation was systemic; 10 (22\%) exhibited oral allergy syndrome, and 7 (15\%) experienced contact urticaria. Most major allergens were found between $27 \mathrm{kDa}$ and $47 \mathrm{kDa}$. ELISA inhibition assays revealed a high degree of inhibition of cephalopods and bivalves from all the groups of mollusks, mites, and crustaceans. Mass spectrometry identified tropomyosin, actin, and myosin as the major allergens.

Conclusions: Cephalopods, especially squid, are the mollusks that most frequently trigger allergic symptoms. The very frequent occurrence of allergy to limpets is striking, given their low consumption in our area. It is worth highlighting the heterogeneity observed, exemplified by the gastropods. Tropomyosin appears to be responsible for the high cross-reactivity found between mollusks, mites, and crustaceans. Three new mollusk allergens were also identified, namely, actin, enolase, and a putative C1q domain-containing protein.

Key words: Mollusk. Allergy. Allergens. 


\section{Resumen}

Introducción: La alergia a moluscos ha sido menos estudiada y está peor caracterizada que la alergia a crustáceos.

Objetivo: Describir las características clínicas de pacientes alérgicos a moluscos, identificar los alérgenos responsables y estudiar la reactividad cruzada entre ellos.

Métodos: Estudio multicéntrico, prospectivo. Se incluyen 45 pacientes con alergia a moluscos, definida como una clínica sugestiva y prueba cutánea positiva con el molusco sospechoso. Se identificaron las bandas alergénicas mediante SDS-PAGE e inmunodetección. Las proteínas responsables se identificaron utilizando espectrometría de masas. Se realizaron ensayos de inhibición de ELISA entre moluscos, ácaros y crustáceos.

Resultados: Veinticinco (55\%) de los pacientes eran alérgicos a cefalópodos, 14 (31\%) a bivalvos y 11 (24\%) a gasterópodos. La lapa resultó ser la tercera causa de alergia (15\% de los casos). Los síntomas fueron sistémicos en 31 pacientes $(69 \%)$, diez (22\%) tuvieron síndrome de alergia oral y siete (15\%) urticaria de contacto. La mayoría de las bandas alergénicas estaban entre 27 y $47 \mathrm{kDa}$. Los ensayos de inhibición de ELISA mostraron un alto grado de inhibición de cefalópodos y bivalvos por parte de moluscos, ácaros y crustáceos. Mediante espectometría de masas se identificaron tropomiosina, actina y miosina como los alérgenos mayoritarios.

Conclusiones: Los moluscos que con más frecuencia provocan reacciones alérgicas son los cefalópodos, especialmente el calamar. Llama la atención la elevada frecuencia de alergia a la lapa, a pesar de su bajo consumo. También hay que resaltar la heterogeneidad observada, por ejemplo en los gasterópodos. La tropomiosina parece ser responsable de la elevada reactividad cruzada encontrada entre moluscos, ácaros y crustáceos. Se han identificado tres nuevos alérgenos en los moluscos: actina, enolasa y putative C1q domain-containing protein. Palabras clave: Moluscos. Alergia. Alérgenos.

\section{Introduction}

Seafood plays an important role in human nutrition and health. However, shellfish, including crustaceans and mollusks, are one of the most common causes of food allergy in the world. Within the group of edible mollusks, we can identify 3 classes: cephalopods (squid, cuttlefish, and octopus), bivalves (mussels, clams, razor fish, winkles, oysters, and scallops), and gastropods (limpets, snails, and abalone). Although the importance of mollusk allergy is becoming increasingly recognized, its prevalence is unknown. In a nationwide random telephone survey in the USA, Sicherer et al [1] found a self-reported prevalence of $0.4 \%$. Rance et al [2] obtained a self-reported prevalence of $0.15 \%$ in French children. In Spain, Crespo et al [3] reported that mollusks were responsible for $1.6 \%$ of food allergies in a sample of children.

Given the high levels of consumption of shellfish and their early introduction into the diet in southeast Asia and Japan, a large number of studies on mollusk allergy in this area have been published [4].

As is the case in crustaceans, tropomyosin appears to be the most important allergen identified to date in the 3 classes of mollusk [4]. The protein paramyosin has also been identified [5]. However, a considerable number of allergens remain unidentified [4].

Although in vitro cross-reactivity between mollusks and crustaceans is extremely high [6], patients allergic to crustaceans very frequently tolerate mollusks and vice versa, possibly because of the presence of different epitopes of tropomyosin in the 2 classes of shellfish and the presence of proteins specific to each class. The homology in the protein sequence of tropomyosin in crustaceans is high (98\%), as is that between mollusks (68\%-88\%). Between crustaceans and mollusks, homology ranges from $56 \%$ to $68 \%$ [6-8].

Cross-reactivity between dust mites and crustaceans is also well documented. Within the mollusks, it is striking that the allergic symptoms triggered by gastropods (limpets, snails) invariably occurs in patients with allergy to dust mites, thus indicating the presence of common allergens $[9,10]$.

Furthermore, within mollusks, allergy is most frequently limited to some of the 3 classes described above (cephalopods, bivalves, and gastropods), thus suggesting the presence of several proteins or at least differences in antigenic recognition of the same.

In the literature, there are no extensive series of patients with allergy to mollusks in which immunologic analyses have also been performed. The primary objective of this study was to analyze the clinical characteristics of a group of molluskallergic patients in Spain. The secondary objectives were to identify the proteins responsible for the allergy and assess the degree of cross-reactivity between them, as well as crossreactivity with allergens from crustaceans and mites.

\section{Materials and Methods}

\section{Patients}

Sera from 45 mollusk-allergic patients were collected from Hospital Universitario Central de Asturias (Asturias), Hospital de Cruces (Vizcaya), Hospital Virgen del Camino (Navarra), Hospital Universitario de Araba (Álava), Hospital Donostia (Guipúzcoa), Clínica Universidad de Navarra (Navarra), Hospital de Basurto (Vizcaya), Hospital de Mendaro (Guipúzcoa), and Hospital de Galdácano (Vizcaya). Patients were recruited during December 2013 and May 2014. Mollusk allergy was diagnosed based on a clear history of adverse reactions suggestive of IgE-mediated allergy after eating a mollusk (cephalopods, bivalves, or gastropods), along with a positive skin prick test result with the same mollusk [11] and negative skin test results to other foods or drugs taken at the same time. In cases where the allergic reaction occurred more than 5 years ago, the patient was included if the diagnosis was 
made at the time of the reaction and the prick test result to the allergenic mollusk remained positive at the time of the study. Patients were included consecutively from among all those who met the inclusion criteria.

Symptoms during the allergic reaction were classified as follows: (1) systemic (urticaria and/or angioedema and/or bronchospasm and/or abdominal symptoms and/or hypotension); (2) contact urticaria (urticarial lesions on contact between the food and the skin); (3) oral allergy syndrome (itching or burning sensation or swelling of the lips, mouth, or pharynx, within minutes after eating the culprit food).

The study was approved by the local ethics committees, and written informed consent was obtained from all patients.

\section{Mollusk, Shrimp, and Mite Extracts}

Mollusk, shrimp, and mite extracts were prepared as follows: $10 \mathrm{~g}$ of each raw material was homogenized in $100 \mathrm{~mL}$ of phosphate-buffered saline and extracted overnight at $4^{\circ} \mathrm{C}$ under constant magnetic stirring. After centrifugation at $14000 \mathrm{~g}$ and $4^{\circ} \mathrm{C}$ for 45 minutes, the supernatant was dialyzed against $\mathrm{NH}_{4} \mathrm{HCO}_{3} 0.1 \mathrm{M}$, lyophilized, and dissolved in phosphate-buffered saline. For in vitro experiments, the protein concentration was adjusted to $1 \mathrm{mg} / \mathrm{mL}$.

\section{Skin Tests}

All patients underwent a prick test with Dermatophagoides pteronyssinus (ALK-Abelló) and a prick-by-prick test with shrimp (Parapenaeus longirostris) using the same material in all hospitals. Each patient reported the type of mollusk that triggered the allergic symptoms in order to administer the prick-by-prick test with the same agent. A skin test was considered positive if a wheal $>3 \mathrm{~mm}$ in diameter (ie, greater than the negative control) was observed.

\section{Specific IgE}

The ImmunoCAP FEIA 250 test (Thermo Fisher Scientific) was used to determine the presence of specific IgE against the mollusk triggering the allergic reaction and against shrimp tropomyosin (rPen a 1).

\section{SDS-PAGE and Immunoblot Analysis}

SDS-PAGE was carried out according to Laemmli [12] using the Hoefer SE 600 electrophoresis system (GE Healthcare). Gels were separated and stacked using polyacrylamide concentrations of $14 \%(\mathrm{wt} / \mathrm{vol})$ and $5 \%(\mathrm{wt} / \mathrm{vol})$, respectively. Twenty micrograms of protein extract was applied per lane. The samples were mixed with $0.1 \mathrm{M}$ Tris, $\mathrm{pH} 6.8$, containing $4 \%$ (wt/vol) SDS, 20\% (wt/vol) glycerol, $10 \%$ (wt/vol) 2 - $\beta$-mercaptoethanol, and $0.02 \%$ (wt/vol) bromophenol blue. To ensure proper protein separation and visualization, the gels were stained with PageBlue Protein Staining Solution (Fermentas International, Inc) or used for immunoblotting as described below. Immunodetection was carried out as previously described [13] with the 45 individual sera from mollusk-allergic patients. Sera from 5 nonatopic patients were used as negative controls.

\section{Protein Identification and Characterization by Mass Spectrometry}

Protein bands recognized by the sera of more than $50 \%$ of patients were selected for further study. Bands were extracted from the gel, and proteins were identified by mass spectrometry (MS) using liquid chromatography-MS/MS, as previously described [13]. Proteins were identified by searching a nonredundant protein sequence database (NCBI) using the Mascot program (http://www.matrixscience.com).

\section{ELISA and ELISA Inhibition Studies}

ELISA and ELISA inhibition assays were carried out using 96-well flat-bottom plates (Immulon 4HBX, Thermo Scientific), as previously described [14]. The plates were coated in duplicate overnight at $4^{\circ} \mathrm{C}$ with $10 \mu \mathrm{g}$ of mollusk proteins per well diluted in coating buffer $(0.05 \mathrm{M}$ carbonatebicarbonate buffer, $\mathrm{pH}$ 9.6). Sera from patients allergic to each mollusk were pooled: those of a specific allergy, such sera from squid-allergic patients, were pooled for inhibition of coated squid extract. Sera from 5 nonatopic patients were used as negative controls. IgE reactivity was considered positive when a patient's optical density at $620 \mathrm{~nm}$ was 2 times higher than a negative control's optical density at the same absorbance. All tests were performed in duplicate. For ELISA inhibition assays, a mollusk extract (10 $\mu \mathrm{g})$ was used as the solid phase and pooled sera from allergic patients were preincubated for 4 hours at room temperature with $100 \mu \mathrm{g}$ of the inhibitor (protein extract) per milliliter of serum.

\section{Results}

\section{Clinical Features}

The study population comprised 45 patients. Table 1 shows demographic data, clinical characteristics, and the results of skin tests and specific IgE determinations to mollusks and shrimp tropomyosin.

The median (IQR) age of the patients was 30 (17-40) years (24 male). The mean time between the last reaction and the study was 5 years.

The distribution by class of mollusk can be seen in Table 2 . Five patients (11\%) were allergic to cephalopods and bivalves. Three patients presented with allergic reactions to several mollusks from the same group, cephalopods, and gastropods.

Symptoms were systemic in 31 of the 45 patients $(69 \%)$. Ten $(22 \%)$ presented oral allergy syndrome and 7 (15\%) contact urticaria. Systemic reactions were recorded in $100 \%$ of gastropod-allergic patients, $80 \%$ of bivalve-allergic patients, and $67 \%$ of cephalopod-allergic patients.

\section{Mite Allergy}

Symptoms of rhinitis and/or asthma due to dust mites were detected in 29 patients (64\%) with the following distribution: 11 cases in gastropod-allergic patients $(100 \%), 13$ cases in cephalopod-allergic patients $(55 \%)$, and 5 in bivalve-allergic patients $(50 \%)$.

A skin test to mites was positive in 35 patients (78\%). 
Table 1. Clinical Features of Mollusk-Allergic Patients

\begin{tabular}{|c|c|c|c|c|c|c|c|c|c|}
\hline Patient & Age, y & Mollusk & $\begin{array}{l}\text { Mollusk } \\
\text { Symptoms }\end{array}$ & $\begin{array}{l}\text { Mite } \\
\text { Allergy }\end{array}$ & $\begin{array}{c}\text { Mite } \\
\text { Skin Test }\end{array}$ & $\begin{array}{c}\text { Crustacean } \\
\text { Allergy }\end{array}$ & $\begin{array}{l}\text { Shrimp } \\
\text { Skin Test }\end{array}$ & $\begin{array}{c}\text { Specific IgE } \\
\text { to Mollusk, } \\
\mathrm{kU}_{\mathrm{A}} / \mathrm{La}\end{array}$ & $\begin{array}{c}\text { Specific } \operatorname{IgE} \\
\text { to } \mathrm{rPen} \text { a } 1 \text {, } \\
\mathrm{kU}_{\mathrm{A}} / \mathrm{L}\end{array}$ \\
\hline 1 & 35 & $\mathrm{Sq}, \mathrm{C}$ & OAS & - & + & + & + & 0.85 & 20.7 \\
\hline 2 & 7 & $\mathrm{Sq}, \mathrm{C}$ & OAS & + & + & + & + & 2.13 & 26.5 \\
\hline 3 & 27 & $\mathrm{Sq}$ & $\mathrm{S}$ & + & + & + & + & 0.06 & 2.98 \\
\hline 4 & 47 & $\mathrm{Sq}$ & $\mathrm{S}$ & + & + & + & + & 0.03 & 0 \\
\hline 5 & 37 & $\mathrm{Sq}$ & $\mathrm{CU}$ & + & + & - & - & 0 & 2.19 \\
\hline 6 & 35 & $\mathrm{Sq}, \mathrm{O}, \mathrm{Cu}, \mathrm{M}, \mathrm{C}, \mathrm{Co}$ & $\mathrm{S}$ & + & + & + & + & 1.51 & 11.4 \\
\hline 7 & 6 & $\mathrm{Sq}, \mathrm{Cu}$ & $\mathrm{CU}$ & - & + & - & + & 0.31 & 2.14 \\
\hline 8 & 14 & $\mathrm{Sq}$ & OAS & + & + & + & + & 0.08 & 0.1 \\
\hline 9 & 12 & $\mathrm{Sq}$ & $\mathrm{CU}$ & + & + & - & + & 0.36 & 3.81 \\
\hline 10 & 47 & $\mathrm{Sq}$ & $\mathrm{S}$ & - & - & + & + & 0 & 0.23 \\
\hline 11 & 17 & $\mathrm{Sq}$ & $\mathrm{OAS}, \mathrm{CU}$ & + & + & - & - & 0.37 & 0 \\
\hline 12 & 70 & $\mathrm{Sq}$ & $\mathrm{S}$ & - & - & + & + & 0 & 0.85 \\
\hline 13 & 25 & $\mathrm{Sq}$ & OAS & + & + & + & + & 0 & 0 \\
\hline 14 & 18 & $\mathrm{Sq}$ & $\mathrm{CU}$ & + & + & + & + & 0.06 & 6.13 \\
\hline 15 & 25 & $\mathrm{Sq}$ & $\mathrm{S}, \mathrm{CU}$ & - & - & + & + & 7.34 & 1.5 \\
\hline 16 & 20 & $\mathrm{Sq}$ & $\mathrm{S}$ & - & + & - & + & 0.03 & 4.72 \\
\hline 17 & 16 & $\mathrm{Sq}$ & OAS & - & + & + & + & 0.32 & 8.76 \\
\hline 18 & 18 & $\mathrm{Sq}$ & OAS & + & + & - & + & 0.67 & 0 \\
\hline 19 & 34 & $\mathrm{O}$ & $\mathrm{S}$ & - & - & - & + & 0.03 & 0 \\
\hline 20 & 28 & $\mathrm{O}$ & $\mathrm{S}$ & - & - & - & - & 0 & 0 \\
\hline 21 & 40 & $\mathrm{O}$ & $\mathrm{CU}$ & - & + & - & - & 0.25 & 0 \\
\hline 22 & 30 & $\mathrm{Cu}$ & $\mathrm{S}$ & - & - & - & + & ND & 0.61 \\
\hline 23 & 23 & $\mathrm{Cu}$ & $\mathrm{S}$ & + & + & + & + & ND & 3.59 \\
\hline 24 & 15 & $\mathrm{Cu}, \mathrm{C}$ & $\mathrm{S}$ & + & + & + & + & ND & 13.8 \\
\hline 25 & 17 & M & $\mathrm{S}$ & - & - & - & - & 0 & 0 \\
\hline 26 & 40 & M & $\mathrm{S}$ & - & - & - & + & 1.49 & 0 \\
\hline 27 & 20 & M & OAS & + & + & + & + & 0.41 & 3.23 \\
\hline 28 & 17 & $\mathrm{C}, \mathrm{O}$ & $\mathrm{S}$ & + & + & + & + & 0.24 & 1.04 \\
\hline 29 & 49 & $\mathrm{C}$ & $\mathrm{S}$ & + & + & + & + & 3.09 & 13.4 \\
\hline 30 & 40 & $\mathrm{C}$ & $\mathrm{S}$ & + & + & + & + & 1.6 & 4.15 \\
\hline 31 & 33 & $\mathrm{C}$ & $\mathrm{S}$ & - & - & - & + & 0.56 & 0 \\
\hline 32 & 26 & $\mathrm{R}$ & $\mathrm{S}$ & + & + & - & - & ND & 0.02 \\
\hline 33 & 14 & $\mathrm{R}$ & $\mathrm{OAS}, \mathrm{CU}$ & - & + & - & - & ND & 0 \\
\hline 34 & 78 & $\mathrm{R}$ & $\mathrm{S}$ & - & - & - & + & ND & 0 \\
\hline 35 & 33 & $\mathrm{~L}$ & $\mathrm{~S}$ & + & + & - & - & 0.16 & 0 \\
\hline 36 & 60 & $\mathrm{~L}$ & $\mathrm{~S}$ & + & + & - & - & 8.9 & 0.11 \\
\hline 37 & 34 & $\mathrm{~L}$ & $\mathrm{~S}$ & + & + & - & - & 0.06 & 0 \\
\hline 38 & 32 & $\mathrm{~L}$ & $\mathrm{~S}$ & + & + & - & - & 0.31 & 0 \\
\hline 39 & 23 & $\mathrm{~L}, \mathrm{Sn}$ & $\mathrm{S}$ & + & + & - & - & 0.13 & 0 \\
\hline 40 & 13 & $\mathrm{~L}$ & $\mathrm{~S}$ & + & + & - & - & 0.13 & 0 \\
\hline 41 & 46 & $\mathrm{~L}$ & $\mathrm{~S}$ & + & + & - & + & 0.91 & 0.05 \\
\hline 42 & 43 & $\mathrm{Sn}$ & $\mathrm{S}$ & + & + & - & + & 0.01 & 0 \\
\hline 43 & 31 & $\mathrm{Sn}$ & $\mathrm{S}$ & + & + & + & + & 0.33 & 0.32 \\
\hline 44 & 59 & $\mathrm{Sn}$ & OAS, S & + & + & - & - & 0.36 & 0.02 \\
\hline 45 & 55 & $\mathrm{Sn}$ & $\mathrm{S}$ & + & + & - & - & 0.01 & 0 \\
\hline
\end{tabular}

Abbreviations: C, clam; Co, cockle; Cu, cuttlefish; CU, contact urticaria; L, limpet; M, mussel; ND, not done; O, octopus; OAS, oral allergy syndrome; S, systemic symptoms; Sn, snail (land); Sq, squid.

almmnunoCAP performed with the triggering mollusk. If there were several mollusks involved, the one considered responsible for the most severe reaction was chosen. 
Of note, the population studied comes from a geographical area with a high incidence of dust mite sensitization.

\section{Crustacean Allergy}

Nineteen patients $(42 \%)$ were allergic to crustaceans based on a clear history of adverse reaction suggestive of IgEmediated allergy, along with a positive skin prick test result.

Table 2. Percentage of Allergy to Each Mollusk

\begin{tabular}{lc}
\hline Mollusk & $\%$ \\
\hline Cephalopods & 55 \\
Squid & 40 \\
Cuttlefish & 11 \\
Octopus & 11 \\
Bivalves & 31 \\
Clam & 18 \\
Mussel & 9 \\
Razor fish & 7 \\
Cockle & 2 \\
Gastropods & 24 \\
Limpet & 15 \\
Snail & 9 \\
\hline
\end{tabular}

$$
\text { A }
$$

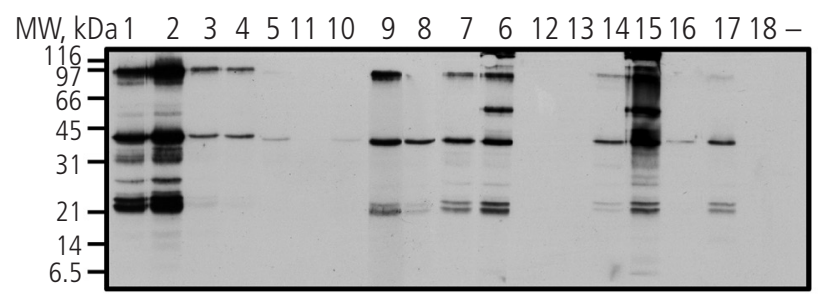

B

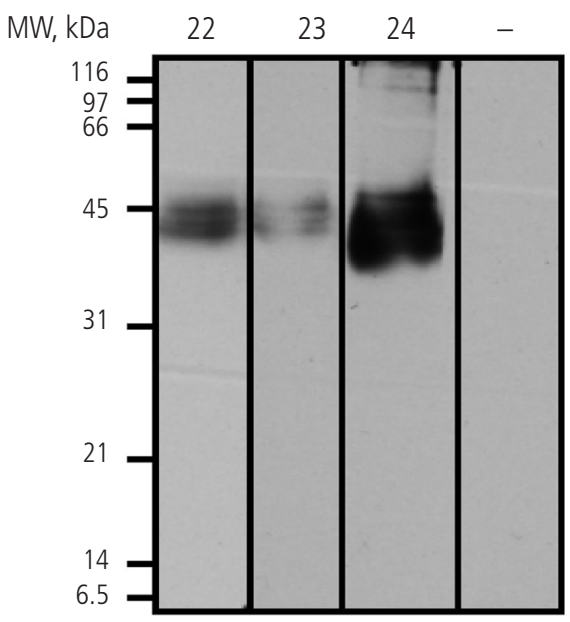

Figure 1. IgE-binding bands in mollusk extract by immunoblotting. Panel A, Squid. Panel B, Cuttlefish. The lane number represents the patient serum number. Lane $(-)$ represents a negative control of pooled sera from nonatopic patients. MW indicates molecular weight markers $(\mathrm{kDa})$.
The findings by class of mollusk were 14 cases in cephalopodallergic patients (58\%), 4 in bivalve-allergic patients (40\%), and 1 in gastropod-allergic patients (9\%).

A total of 30 patients $(66 \%)$ had a positive skin test result to crustaceans.

A

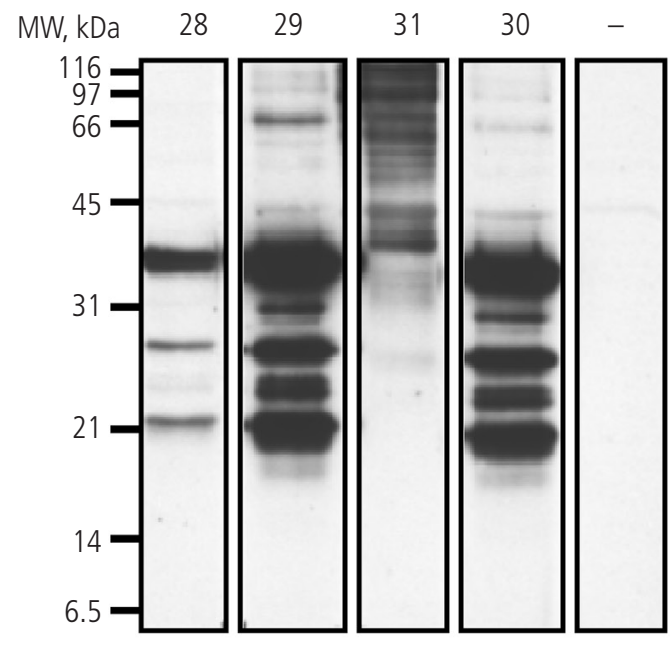

B

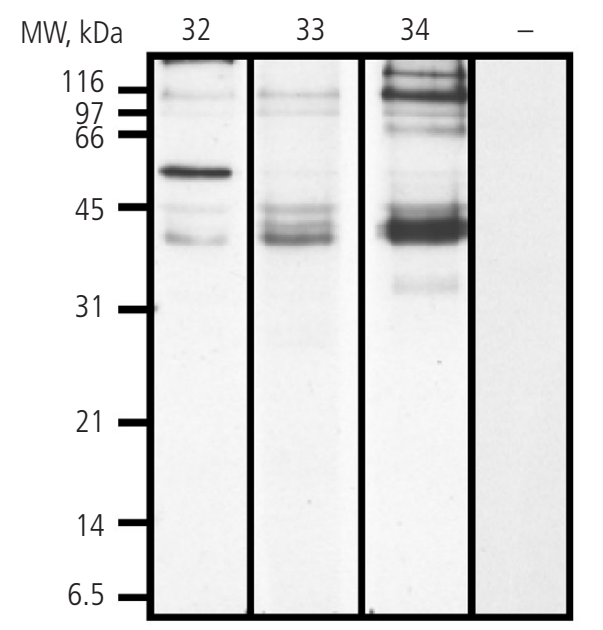

C

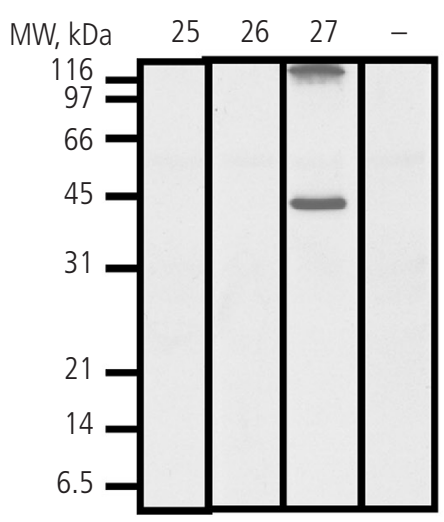

Figure 2. IgE-binding bands in mollusk extract by immunoblotting. Panel A, Clam. Panel B, Razor fish. Panel C, Mussel. The lane number represents the serum patient number. Lane $(-)$ represents a negative control of pooled sera from nonatopic patients. MW indicates molecular weight markers $(\mathrm{kDa})$. 


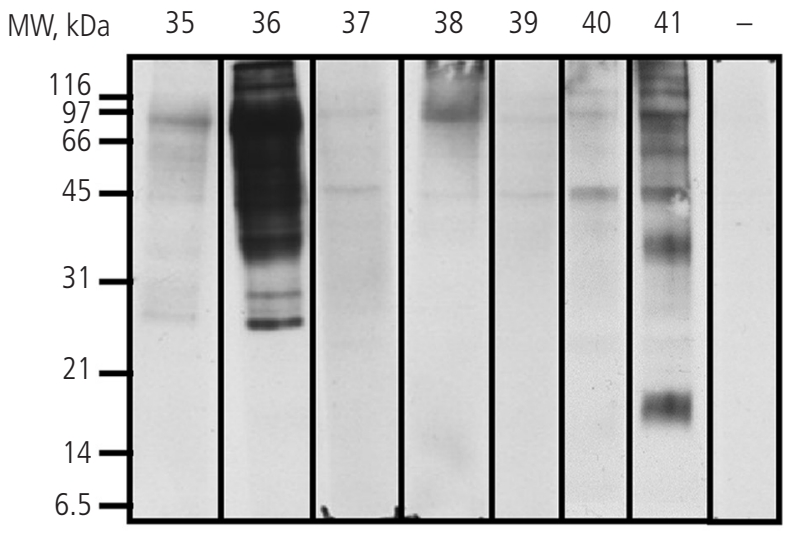

Figure 3. IgE-binding bands in limpet extract by immunoblotting. The lane number represents the serum patient number. Lane $(-)$ represents a negative control of pooled sera from nonatopic patients. MW indicates molecular weight markers ( $\mathrm{kDa})$.

\section{Specific $\lg E$}

Specific IgE to the triggering mollusk of the allergic reaction was detected in $83 \%$ of patients (cutoff point of $0.1 \mathrm{kU}_{\mathrm{A}} / \mathrm{L}$ ). This percentage fell to $52 \%$ when the cutoff point was $0.35 \mathrm{kU}_{\mathrm{A}} / \mathrm{L}$.

IgE to $\mathrm{rPen}$ a 1 greater than $0.1 \mathrm{kU}_{\mathrm{A}} / \mathrm{L}$ was recorded in $51 \%$ of the series. This percentage fell to $44 \%$ when the cutoff point used was $0.35 \mathrm{kU}_{\mathrm{A}} / \mathrm{L}$. When the result was evaluated according to the type of mollusk and taking $0.1 \mathrm{kU}_{\mathrm{A}} / \mathrm{L}$ as the reference value, we obtained a positive result to rPen a 1 in $72 \%$ of cephalopod-allergic patients, $57 \%$ in the bivalve-allergic group, and $18 \%$ in the gastropodallergic group.

\section{Immunoblot Analysis}

Cephalopods. Immunoblot analysis revealed IgE-binding bands in 14 of the 18 squid-allergic patients (Figure 1A), especially those with an apparent molecular weight of 22, 24, 38 , and $100 \mathrm{kDa}$, which were seen in more than $50 \%$ of the patients. The 3 cuttlefish-allergic patients had IgE-binding bands with an apparent molecular weight of $38 \mathrm{kDa}$ and $40 \mathrm{kDa}$ (Figure 1B).

Bivalves. IgE-binding bands were found in all clam-allergic patients. The bands that appeared in more than $50 \%$ of patients corresponded to 20,27, and $36 \mathrm{kDa}$ (Figure 2A). In the case of razor fish, the most frequent bands in the 3 allergic patients were 42, 44, and $45 \mathrm{kDa}$ (Figure 2B). An IgE-binding band corresponding to $40 \mathrm{kDa}$ was detected in only 1 mussel-allergic patient (Figure 2C).

Gastropods. IgE-binding bands were found in all limpetallergic patients. These corresponded to $46 \mathrm{kDa}$ and $47 \mathrm{kDa}$ (Figure 3).

In patients allergic to octopus and snails, no IgEbinding bands were found for any of the extracts (data not shown). Control immunoblot assays with the pooled sera from nonatopic patients did not reveal any IgE-binding bands.
Table 3. Protein Identification by Mass Spectrometry

\begin{tabular}{|c|c|c|c|}
\hline Mollusk & $\begin{array}{c}\text { Apparent } \\
\text { Molecular Weight }\end{array}$ & Identification & $\begin{array}{c}\% \\
\text { Recognition }\end{array}$ \\
\hline \multirow[t]{8}{*}{ Clam } & 20 & Tropomyosin & 50 \\
\hline & 23 & $\beta$-Actin & 75 \\
\hline & 24 & $\beta$-Actin & 50 \\
\hline & 27 & Actin & 72 \\
\hline & 30 & Actin & 50 \\
\hline & 31 & $\beta$-Actin & 50 \\
\hline & 34 & Actin & 75 \\
\hline & 36 & Tropomyosin & 75 \\
\hline \multirow[t]{8}{*}{ Squid } & 22 & Tropomyosin & 50 \\
\hline & 24 & Tropomyosin & 50 \\
\hline & 35 & Tropomyosin & 22 \\
\hline & 38 & Actin & 22 \\
\hline & 40 & Actin & 78 \\
\hline & 55 & Myosin & 22 \\
\hline & 60 & Myosin & 11 \\
\hline & 100 & Myosin & 50 \\
\hline \multirow[t]{5}{*}{ Razor fish } & 40 & Actin & 100 \\
\hline & 42 & Actin & 67 \\
\hline & 44 & Actin & 67 \\
\hline & 45 & Actin & 100 \\
\hline & 50 & Enolase & 33 \\
\hline \multirow[t]{2}{*}{ Cuttlefish } & 38 & Tropomyosin & 100 \\
\hline & 40 & Tropomyosin & 100 \\
\hline \multirow[t]{2}{*}{ Limpet } & 46 & Actin & 86 \\
\hline & 47 & Actin & 67 \\
\hline Mussel & 42 & $\begin{array}{c}\text { Putative } \mathrm{Clq} \\
\text { domain-containing } \\
\text { protein }\end{array}$ & 33 \\
\hline
\end{tabular}

\section{Protein Identification by Mass Spectrometry}

Using MS, we identified several IgE-binding proteins: tropomyosin, actin, myosin, and enolase (Table 3 ). The proteins most frequently detected ( $>50 \%$ of patients) by specific $\operatorname{IgE}$ against each mollusk were tropomyosin and myosin in squid, tropomyosin in cuttlefish, tropomyosin and actin in clams, actin in razor fish and limpets, and a putative C1q domaincontaining protein in 1 mussel-allergic patient.

\section{ELISA Inhibition}

The results of the inhibition assays are shown in Figure 4. Squid was widely inhibited by the other cephalopod, cuttlefish. It was also inhibited by the other mollusks, mites and crustaceans. Cuttlefish and clams were also inhibited by the 


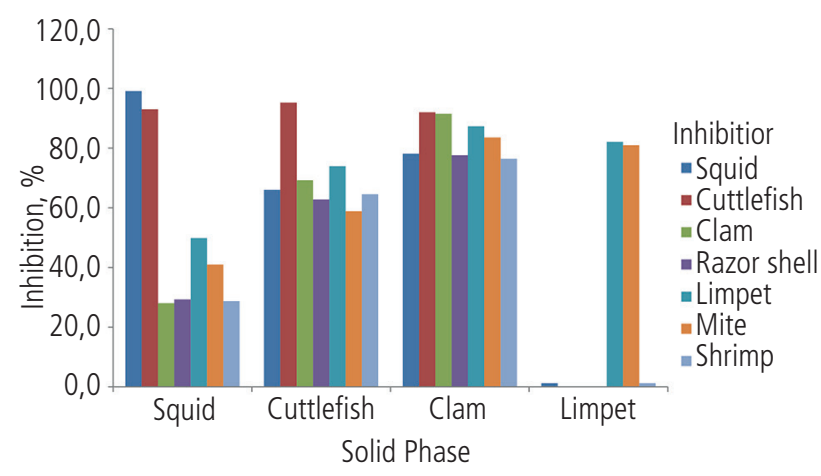

Figure 4. ELISA inhibition assay. A mollusk extract $(10 \mu \mathrm{g})$ was used as the solid phase. Pooled sera were preincubated with other mollusk extracts, mite extract (Dermatophagoides pteronyssinus), and shrimp extract (Penaeus indicus). All tests were performed in duplicate.

remaining mollusks and by mites and crustaceans. Limpets were inhibited only by the mite extract.

\section{Discussion}

The few published studies on allergy to mollusks include a small number of cases. To our knowledge, the present study is the largest to date based on clinical characterization and identification of allergens.

In our series, the most widely represented age group was that of young adults (median age of 30 years), as has been the case in other studies [10,15-19]. Cephalopods were the most frequent mollusk class, particularly squid. This finding is consistent with those published elsewhere [15,20,21]. Bivalves were the second most frequent group, in spite of the fact that they are the most widely consumed mollusk in Spain [22] and probably the world [7]. In the literature, bivalves are the least frequent cause of allergic reactions [7]. We found no cases of allergy to oysters or scallops. Gastropods were the least frequently involved group, with a predominance of limpets. Given the low levels of consumption in Spain, it is striking that this mollusk was the culprit in $15 \%$ of the present series, although this high percentage may be explained by the constant association of this mollusk with allergy to dust mites, which is highly prevalent in the regions we studied. Gastropods are the main trigger in southeast Asia [18,23].

Only $15 \%$ of patients were allergic to several classes of mollusks (cephalopods or bivalves), and 7\% were allergic to several mollusks from the same group (cephalopods or gastropods). However, the inhibition assays revealed important cross-reactivity between cephalopods and bivalves (Figure 4). The reason for this difference may be that patients who have had an allergic reaction to one mollusk subsequently tend to avoid new exposures to any other mollusk. The case of gastropods is different, as these are not inhibited by other groups of mollusk, thus explaining why we found no patients who were allergic both to gastropods and to cephalopods or bivalves.

It is worth highlighting that although most of the patients $(69 \%)$ experienced systemic reactions, one third only had oral allergy syndrome and/or contact urticaria.
In the literature, systemic reactions have been reported, but no reference has been made to other types of clinical manifestation. Interestingly, all patients with allergy to gastropods had systemic symptoms, although this was not the case for bivalves and cephalopods. Other studies have also reported this finding $[10,16,19]$. Patients are almost always dust mite-allergic asthmatics who frequently develop serious bronchospasm or anaphylaxis immediately after eating the gastropod, as occurred in the cases we report.

Rhinitis and/or asthma due to mites were detected in $64 \%$ of patients, although almost $80 \%$ were sensitized to the same allergen. Similarly, we found mites to inhibit the allergenicity of all the mollusk groups (Figure 4). This link has been reported in most studies, although it is sometimes difficult to separate the group with allergy to mollusks from those who are also allergic to crustaceans $[15,18]$.

In the present series, $42 \%$ of patients were allergic to crustaceans, with a high frequency in those who were allergic to cephalopods (58\%); in contrast, only 1 case was found among gastropod-allergic patients $(9 \%)$. This association between allergy to crustaceans and mollusks has been widely recognized in the literature [24]. The degree of skin sensitization to both has been reported to be as high as $90 \%$ [18], although in our study it was only $66 \%$. Similarly, in our inhibition assays, cephalopods were widely inhibited by crustaceans (Figure 4). Nevertheless, $40 \%$ of cephalopod-allergic patients and $60 \%$ of bivalve-allergic patients tolerated crustaceans. The results were more homogeneous for gastropods: we found no inhibition by crustaceans (Figure 4), only $9 \%$ had positive skin test results to crustaceans, and $100 \%$ tolerated crustaceans, a finding reported in previous studies $[10,16]$. We believe, therefore, that mollusk-allergic patients should be managed on an individual basis. Furthermore, we disagree with the widely held view that all types of shellfish should be avoided $[6,9,15]$, so that diets are not unnecessarily restricted. We consider that an oral food challenge should be performed if recent tolerance to a specific mollusk is not known.

It is worth highlighting that immunoblot analyses did not reveal any IgE-binding bands for octopus and snails, either under reducing or nonreducing conditions. We have no explanation for this finding, since all these patients presented an unequivocal allergic reaction (as did the rest of the series) and specific IgE against these mollusks was found using skin tests. A possible explanation could be the low level of specific IgE obtained against both mollusks. Nevertheless, in the case of other mollusks, immunoblotting revealed IgE-binding bands despite very low - or even undetectable - levels of specific IgE.

Tropomyosin is the most widely reported allergen in mollusks [4] and has been identified in cephalopods [25,26], bivalves [27,28], and gastropods [29]. It should be noted that in some of these studies, the sera used came from patients who were allergic to crustaceans. In our series, the protein was identified in squid, cuttlefish, and clams. We observed a directly proportional relationship between specific IgE levels to shrimp tropomyosin and the intensity of the immunoblotting bands identified in MS as tropomyosin.

Tropomyosin is also thought to be responsible for the cross-reactivity between mollusks, between mollusks and 
crustaceans, and between both groups and dust mites; this cross-reactivity reached high levels in vitro [4]. Consistent with this observation, we found that most of the patients who were allergic to several classes of mollusks were also allergic to those in which tropomyosin was identified as the allergen (squid, cuttlefish, and clam). Furthermore, in the inhibition assays, these mollusks inhibit one another and are in turn inhibited by mites and crustaceans, both of which contain tropomyosin (Figure 4). The presence of different epitopes in each of these groups, and in each mollusk in particular, could be the cause of the variability we observed. The sequence homology of tropomyosin in crustaceans is high, $98 \%$, as it is between mollusks, $68 \%$ to $88 \%$, while between crustaceans and mollusks it ranges from $56 \%$ to $68 \%[6,8]$. We found no differences when we compared the immunoblotting patterns of patients who were allergic only to mollusks with those of patients who were allergic to mollusks and crustaceans. This runs counter to the notion of the presence of mollusk-specific allergens, which could explain the existence of both groups of patients. However, there are also isolated reports of allergy to mollusks in patients who tolerate crustaceans, in which tropomyosin does not appear to be implicated [30-34].

In addition to tropomyosin, the only allergen identified at the molecular level in mollusks was myosin (molecular weight of $100 \mathrm{kDa}$ ), the well-known major allergen in abalone [5]. Again it must be noted that the sera used in the study came from crustacean-allergic patients with no documented allergic reaction to mollusks. In the present series, we characterized 3 new allergens in mollusks: actin as the major allergen in razor fish and limpet, with a molecular weight of $45 \mathrm{kDa}$; enolase, with a weight of $50 \mathrm{kDa}$ in razor fish; and a putative $\mathrm{C} 1 \mathrm{q}$ domain-containing protein of $42 \mathrm{kDa}$ in mussel.

We found that the gastropods showed very high crossreactivity with dust mites, both clinically and in vitro, whereas other mollusks and crustaceans did not. The fact that we did not identify tropomyosin as an allergen in limpets would argue against a role for this protein in the cross-reactivity between gastropods and mites, a possibility that has been raised in other studies [9,10,35,36]. Abdel Rahman et al [37] reported $\alpha$-actin to be a new crustacean allergen, and Gámez et al [38] showed that it was linked to mite-crustacean cross-reactivity. Our identification of actin in limpets could point to a role in the cross-reactivity between mites and gastropods.

The main limitation of our study is that it does not include the gold standard of food allergy diagnosis, the double-blind placebo-controlled food challenge (DBPCFC). However, its prospective design means that the data collected are highly reliable, and the fact that the patients selected had an unequivocal history of IgE-mediated processes confirmed by skin prick tests means that the diagnosis of allergy to mollusks was made with very high levels of accuracy. Furthermore, analysis of the literature on mollusk allergy shows that the diagnoses were based on the same criteria as those used in our study, without the inclusion of the DBPCFC [10,15-18,20,39].

In summary, our analysis of an extensive series of molluskallergic patients shows that squid was the most frequently involved mollusk in our setting and that allergy to limpet was very frequent, despite the minimum levels of consumption of this gastropod. Although allergic reactions to mollusks are always reported to be systemic, we highlight the absence of such reactions in one third of our patients. Furthermore, we identified actin, enolase, and a putative $\mathrm{C} 1 \mathrm{q}$ domain-containing protein as new allergens in mollusks. When tropomyosin was shown to be an allergen, it was responsible for the high cross-reactivity between mollusks, mites, and crustaceans. The heterogeneity between mollusks, as exemplified by the gastropods, should also be noted. Finally, mollusk-allergic patients should be managed on an individual basis, as occurs with tree nut-allergic patients, so that diets are not unnecessarily restricted.

\section{Acknowledgments}

C Pastor, G Gastaminza, and MJ Goikoetxea belong to the Spanish Research Network on Adverse Reactions to Allergens and Drugs (RIRAAF: Red de Investigación de Reacciones Adversas a Alérgenos y Fármacos), which is supported by the Carlos III Health Institute (Grant RD12/0013/00010 and RD12/0013/00013).

\section{Funding}

This study was supported by a grant from ALERGONORTE (Sociedad de Alergia del Norte de España). We thank Dr Borja Bartolomé (Bial) for supplying the allergen extracts. The proteomic analysis was performed in the Proteomics Unit of the Complutense University of Madrid, which belongs to ProteoRed, PRB2-ISCIII, and is supported by grant PT13/0001.

\section{Conflicts of Interest}

The authors declare that they have no conflicts of interest.

\section{References}

1. Sicherer SH, Muñoz-Furlong A, Sampson HA. Prevalence of seafood allergy in the United States determined by a random telephone survey. J Allergy Clin Immunol. 2004;114:159-65.

2. Rance F, Grandmottet $X$, Grandjean H. Prevalence and main characteristics of schoolchildren diagnosed with food allergies in France. Clin Exp Allergy. 2005;35:167-72.

3. Crespo JF, Pascual C, Burks AW, Helm RM, Esteban MM. Frequency of food allergy in a pediatric population from Spain. Pediatr Allergy Immunol. 1995;6:39-43.

4. Leung NY, Wai CY, Shu S, Wang J, Kenny TP, Chu KH, Leung PS Current immunological and molecular biological perspectives on seafood allergy: a comprehensive review. Clin Rev Allergy Immunol. 2014:46:180-97.

5. Suzuki M, Kobayashi, Y, Hiraki Y, Nakata H, Shiomi $K$. Paramyosin of the disc abalone Haliotis discus discos: identification as a new allergen and cross-reactivity with tropomyosin. Food Chemistry. 2011;124:921-6.

6. Ayuso R. Update on the diagnosis and treatment of shellfish allergy. Curr Allergy Asthma Rep. 2011:11(4):309-16.

7. Taylor SL. Molluscan shellfish allergy. Adv Food Nutr Res. 2008;54:139-77.

8. Pedrosa M, Boyano-Martínez T, García-Ara C, Quirce S. Shellfish Allergy: a Comprehensive Review. Clin Rev Allergy Immunol. 2015;49;203-16. 
9. Van Ree R, Antonicelli L, Akkerdaas JH, Pajno GB, Barberio G, Corbetta L, Ferro G, Zambito M, Garritani MS, Aalberse RC, Bonifazi F. Asthma after consumption of snails in house-dustmite-allergic patients: a case of IgE cross-reactivity. Allergy. 1996:51:387-93.

10. Azofra J, Lombardero M. Limpet anaphylaxis: cross-reactivity between limpet and house-dust mite Dermatohagoides pteronyssinus. Allergy. 2003;58:146-9.

11. Ibañez MD, Alonso E, Blanco C, Cistero A. Metodología diagnóstica en la alergia a alimentos. Alergol Inmunol Clin 1999;14:50-62.

12. Laemmli UK. Cleavage of structural proteins during the assembly of the head of bacteriophage T4. Nature. 1970;227:680-5.

13. Pastor C, Cuesta-Herranz J, Cases B, Pérez-Gordo M, Figueredo $\mathrm{E}$, de las Heras M, Vivanco F. Identification of major allergens in watermelon. Int Arch Allergy Immunol. 2009;149:291-8.

14. Cases B, Pastor-Vargas C, Dones FG, Perez-Gordo M, Maroto AS, de las Heras M, Vivanco F, Cuesta-Herranz J. Watermelon profilin: characterization of a major allergen as a model for plant-derived food profilins. Int Arch Allergy Immunol. 2010;153:215-22

15. Castillo R, Carrillo T, Blanco C, Quiralte J, Cuevas M. Shellfish hypersensitivity: clinical and immunological characteristics. Allergol Immunopathol (Madr). 1994;22:83-7.

16. Carrillo T, Rodríguez de Castro F, Blanco C, Castillo R, Quiralte J, Cuevas M. Anaphylaxis due to limpet ingestion. Allergy. 1994;73:504-8.

17. Nettis E, Pannofino A, Dambra P, Loria MP, Di Maggio G, Damiani E, Ferrannini A, Tursi A. IgE-mediated urticaria/angioedema after ingestion of mussels. Acta Derm Venereol. 2001;81:62.

18. Wu AY, Williams GA. Clinical characteristics and pattern of skin test reactivities in shellfish allergy patients in Hong Kong. Allergy Asthma Proc. 2004;25:237-42.

19. De la Cuesta CG, García BE, Córdoba H, Diéguez I, Oehling A. Food allergy to Helix terrestre (snail). Allergol Immunopathol (Madr). 1989;17:337-9.

20. Turner $\mathrm{P}, \mathrm{Ng}$ I, Kemp A, Campbell D. Seafood allergy in children: a descriptive study. Ann Allergy Asthma Immunol. 2011;106:494-501.

21. Shek LP, Cabrera-Morales EA, Soh SE, Gerez I, Ng PZ, Yi FC, Ma S, Lee BW. A population-based questionnaire survey on the prevalence of peanut, tree nut, and shellfish allergy in 2 Asian populations. J Allergy Clin Immunol. 2010;126:324-31.

22 http://www.mercasa.es/files/multimedios/1350549299_ pag_005-020_Martin-Cerdeno.pdf.

23. Thong BY, Cheng YK, Leong KP, Tang CY, Chng HH. Anaphylaxis in adults referred to a clinical immunology/allergy centre in Singapore. Singapore Med J. 2005;46:529-34.

24. Lopata AL, O'Hehir RE, Lehrer SB. Shellfish allergy. Clin Exp Allergy. 2010;40:850-8.

25. Ishikawa M, Suzuki F, Ishida M, Nagashima $Y$, Shiomi K. Identification of tropomyosin as major allergen in the octopus Octopus vulgaris and elucidation of its lgE-binding epitopes. Fish Sci. 2001;67:934-42.

26. Yadzir ZH, Misnan R, Murad S. Identification of tropomyosin as major allergen of white squid (Loligo edulis) by twodimensional immunoblotting and mass spectrometry. Southeast Asian J Trop Med Public Health. 2012;43:185-91.
27. Emoto Ai, Ishizaki S, Shiomi K. Tropomyosins in gastropods and bivalves: identification as major allergens and amino acid sequence features. Food Chem. 2009:114;634-41.

28. Chu KH, Wong SH, Leung PS. Tropomyosin is the major mollusc Allergen: Reverse Transcriptase Polymerase Chain Reaction, Expression and IgE Reactivity. Mar Biotechnol. (NY). 2000;2:499-509.

29. Asturias JA, Eraso $E$, Arilla $M C$, Gómez-Bayón $N$, Inácio $F$, Martínez A. Cloning, isolation, and IgE-binding properties of Helix aspersa (brown garden snail) tropomyosin. Int Arch Allergy Immunol. 2002;128:90-6.

30. Jiménez M, Pineda F, Sánchez I, Orozco I, Senent C. Allergy due to Ensis macha. Allergy. 2005;60:1090-1.

31. Martín-García C, Carnés J, Blanco R, Martínez-Alonso JC, Callejo-Melgosa A, Frades A, Colino T. Selective hypersensitivity to boiled razor shell. J Investig Allergol Clin Immunol. 2007;17:271-3.

32. San Miguel-Moncín M, Pineda F, Llamas E, Amat P, García R, García-Rubio I, Lluch M, Malet M. Octopus hypersensitivity. Allergy. 2007;62 (Suppl. 83):330.

33. Rodríguez del Río P, Sánchez-López J, Robledo T, MartínezCócera C, Fernández-Rivas M. Selective allergy to Venus antiqua clam. Allergy. 2009;64:815.

34. Zhang Y, Wang T, Gao S, Morita E. Novel allergen from the freshwater clam and the related allergy. J Dermatol. 2012;39:672-4.

35. Caiado J, Lundberg M, Pedro E, Pereira-Santos MC, Barbosa MP. Snail allergy without house dust mites sensitisation. Allergol Immunopathol (Madr). 2009;37:107-8.

36. Bessot JC, Metz-Favre C, Rame JM, De Blay F, Pauli G. Tropomyosin or not tropomyosin, what is the relevant allergen in house dust mite and snail cross allergies? Eur Ann Allergy Clin Immunol. 2010;42:3-10.

37. Abdel Rahman AM, Kamath SD, Gagné S, Lopata AL, Helleur R. Comprehensive proteomics approach in characterizing and quantifying allergenic proteins from northern shrimp: toward better occupational asthma prevention. J Proteome Res. 2013;12:647-56.

38. Gámez C, Zafra M, Boquete M, Sanz V, Mazzeo C, Ibáñez MD, Sánchez-García S, Sastre J, del Pozo V. New shrimp IgE-binding proteins involved in mite-seafood cross-reactivity. Mol Nutr Food Res. 2014;58:1915-25.

39. Carrillo T, Castillo R, Caminero J, Cuevas M, Rodriguez JC, Acosta O, Rodriguez de Castro F. Squid hypersensitivity: a clinical and immunologic study. Ann Allergy. 1992;68:483-7.

- Manuscript received July 21, 2016; accepted for publication January 3, 2017.

\section{Gabriel Gastaminza}

Departamento de Alergología

Clínica Universidad de Navarra

Pío XX 36

31008 Pamplona, Spain

E-mail: gastaminza@unav.es 